IZA DP No. 10294

Looking Back on the Lessons of "Higher Education and Developing Countries: Peril and Promise":

Perspectives on China and India

David E. Bloom

Philip G. Altbach

Henry Rosovsky

October 2016 


\title{
Looking Back on the Lessons of "Higher Education and Developing Countries: Peril and Promise": Perspectives on China and India
}

\author{
David E. Bloom \\ Harvard T.H. Chan School of Public Health \\ and IZA \\ Philip G. Altbach \\ CIHE, Boston College \\ Henry Rosovsky \\ Harvard University
}

Discussion Paper No. 10294

October 2016

IZA

P.O. Box 7240

53072 Bonn

Germany

Phone: +49-228-3894-0

Fax: +49-228-3894-180

E-mail: iza@iza.org

Any opinions expressed here are those of the author(s) and not those of IZA. Research published in this series may include views on policy, but the institute itself takes no institutional policy positions. The IZA research network is committed to the IZA Guiding Principles of Research Integrity.

The Institute for the Study of Labor (IZA) in Bonn is a local and virtual international research center and a place of communication between science, politics and business. IZA is an independent nonprofit organization supported by Deutsche Post Foundation. The center is associated with the University of Bonn and offers a stimulating research environment through its international network, workshops and conferences, data service, project support, research visits and doctoral program. IZA engages in (i) original and internationally competitive research in all fields of labor economics, (ii) development of policy concepts, and (iii) dissemination of research results and concepts to the interested public.

IZA Discussion Papers often represent preliminary work and are circulated to encourage discussion. Citation of such a paper should account for its provisional character. A revised version may be available directly from the author. 


\section{ABSTRACT \\ Looking Back on the Lessons of "Higher Education and Developing Countries: Peril and Promise": Perspectives on China and India*}

In 2000, Higher Education in Developing Countries: Peril and Promise was published. This influential report, cosponsored by The World Bank and UNESCO, came at a time of transition in higher education worldwide and had some influence on higher education policy and thinking in several developing countries. This article looks at some of the main arguments in Peril and Promise. It focuses particularly on how two key countries, China and India, have developed in light of the key recommendations in Peril and Promise.

JEL Classification: $\quad 125,128,129$

Keywords: higher education, developing countries, higher education policy, peril and promise, China, India

Corresponding author:

David E. Bloom

Department of Global Health and Population

Harvard T. H. Chan School of Public Health

665 Huntington Avenue

Boston, Massachusetts 02115

USA

E-mail: dbloom@hsph.harvard.edu 


\section{Introduction}

In 2000, the independent Task Force on Higher Education and Society published "Higher Education in Developing Countries: Peril and Promise.” The report highlighted the actual and potential contribution of quality higher education to social, economic, and political development. It also identified key obstacles to realizing that potential and various strategies and tools for circumventing those obstacles. Although issued independently, "Peril and Promise" had the backing of the World Bank and UNESCO, and thus the higher education policy community in governments, especially in developing countries, and in international and regional agencies responsible for investment and assistance to education took it seriously.

Considering the period when "Peril and Promise" was published is important. In the early 1990s, World Bank and other economists focused on rate of return analysis and concluded that investment in primary education had the largest return for developing countries (Psacharopoulos 1994). In 1990, the World Bank and UNESCO sponsored an influential conference in Jomtien, Thailand, that strongly advocated for investment in school education and initiated the "Education for All" movement, arguing the "rate of return" logic and the recognized need, at the time, to expand schooling opportunities in developing countries for the many young people without access. One of the results was to substantially reduce investment in higher education in many developing countries, both nationally and multilaterally. These reductions came as middle classes were beginning to expand and the demand for access to postsecondary education was growing - the beginning of the movement we now know as massification. In addition, a growing number of countries were looking to join the emerging global knowledge economy. "Peril and Promise" was, in many ways, the first and most influential argument against the then-popular notion that only primary education, literacy, and women's access to education were needed for development.

Thus, "Peril and Promise" came at a point of transformation in global higher education. The report certainly did not cause the transformation; numerous other forces, including middle class expansion worldwide, increased complexity and sophistication of the labor market, and what some called the "diploma disease" of a perceived necessity for more educational qualifications in the job market contributed to unremitting pressures for expansion.

"Peril and Promise" provided a convincing rationale for refocusing funding and attention on higher education, provided key practical guidance for development and reform of higher education, and presented a vision for the future. It did this with the support of two key organizations, the World Bank and UNESCO, and with the imprimatur of an international group of experts.

Perhaps "Peril and Promise"'s two most important contributions were to relegitimize higher education in the development dialogue and to articulate several key recommendations at a time when higher education institutions were facing dramatic change — in a way charting the "academic revolution" that has unfolded in the $21^{\text {st }}$ century (Altbach, Reisberg, and Rumbley 2010).

This article aims to revisit the main messages of "Peril and Promise" through the lens of a comparative case study of changes in higher education in China and India since publication of the report. Section 1 reviews the main messages and recommendations of the report. Section 2 describes the recent evolution of China's and India's higher education systems in relation to those messages. Section 3 explores other lessons to learn from the higher education experiences of China and India. This section also discusses growing international acknowledgment of higher education as an instrument of development as indicated by its transition from implicit exclusion from the Millennium Development Goals to explicit inclusion in their successors, the Sustainable Development Goals. 


\section{The Relevance of "Peril and Promise" for China and India}

While providing a complete summary of the recommendations in "Peril and Promise" is unnecessary, pointing to several of the main points of the report with special relevance to China and India is useful. Of course, no direct relationship exists between the recommendations in "Peril and Promise” and the policies and practices that China or India have followed. Yet, the policy debates that the report started may have had some impact on discussions in those two countries. "Peril and Promise" certainly stimulated significant global discussion.

The challenge of massification confronted both countries in the first part of the $21^{\text {st }}$ century. China started to address the challenge first — and faced the special difficulty of having gone through the Cultural Revolution between 1966 and 1976, when the entire higher education system was closed. Both countries started with very low gross enrollment rates, less than 10 percent of the 18-23 yearold age group.

With its emphasis on the challenges of expansion, the growing role of the knowledge revolution, and the inevitability of higher education playing an increasingly important role in the educational system and in society, the broader analysis of "Peril and Promise" fit the realities of most developing countries and certainly of China and India. The report's prescriptions concerning the importance of the public interest in shaping higher education policy, approaches to access of increasingly diverse segments of the population, the role of higher education in instilling democratic values, and others have not seemed to play a key role in the two countries' policies as they built up postsecondary institutions in the early years of the $21^{\text {st }}$ century.

In fact, little evidence exists that either country made direct use of the report's recommendations. In the Chinese case, a series of significantly funded programs, mainly to develop and support research universities, succeeded in building up an impressive group of universities that now contribute both to Chinese development and to global higher education. Less comprehensive attention was paid to the bottom of the academic pyramid. India was less successful in building a coherent academic system. This is in part because responsibility for education is in the hands of India's 29 states, few if any of which have had unified visions of postsecondary education or have been able to adequately fund the sector.

Neither China nor India has a comprehensive higher education system serving the increasingly diverse populations in postsecondary education. The development of such systems was a key recommendation of "Peril and Promise", recognizing the increasing and necessary diversity of postsecondary education realities and the need to serve these sectors. Both countries lack an articulated academic system, and so students cannot transfer among institutions, nor can policymakers think about how to integrate the higher education needs of the country. In China's case, the top of the "system" has been well supported, although the mass base has been in general underfunded. In India, little integration exists and overall funding is inadequate. Without question, both countries would benefit from more systematic thinking about their diverse higher education needs. In India particularly, but to some extent in China as well, much of higher education provision is the responsibility of the state and provincial governments, while the central government mainly supports the top universities and research initiatives. With few exceptions in both countries, the states and provinces provide inadequate support. Further, coordination among the states and provinces is sparse. As a result, neither country has a functional academic system. "Peril and Promise" stressed the importance of good governance, both within academic institutions and on a system level, for the success of postsecondary education. However, neither country has created innovative governance arrangements. Academic institutions, with few exceptions, are highly bureaucratic, and the academic community is allowed little power or participation. This is 
true both in the relations between the state and the academic institutions and within institutions themselves. While major differences of course exist between China and India, both countries share this lack of care and attention to good academic governance. "Peril and Promise" focused on the centrality of shared governance-involving academic staff in decision-making and implementation of programs and plans along with administrators and boards of trustees or governors. Shared governance is at the heart of ensuring the participation of the entire academic community - and thus of successful planning and implementation. With few exceptions-a few of China's top universities are making efforts to reform governance and a few of India's institutes of technology have tried to instill participative values - neither country has focused significantly on shared governance. In both countries, academic institutions are highly bureaucratized, and key relations between government and academia are also bureaucratic. China has an added layer of Communist Party bureaucracy within each university and at most levels of government.

The report stressed the importance of science and technology as a key responsibility of universities in the $21^{\text {st }}$ century. China, with its massive initiatives to improve its top 100 universities, has transformed many of these universities so that they are now significant producers of scientific knowledge, research publications, and other outputs. China's growing significance in global academic rankings, which largely measure research productivity, is testimony to the success of this effort. India, however, has not invested in its universities' research capacity, and as a result the country is not a significant contributor to global knowledge, nor have its universities emerged as research institutions.

"Peril and Promise" argued, rather uniquely in discussions of higher education in developing countries at the time and since, that liberal education is an important aspect of undergraduate education that must be part of a coherent curriculum. The report stressed that $21^{\text {st }}$ century society and economy require a breadth of knowledge and skills in thinking, writing, and communication, and emphasized that narrow specialization will not serve graduates well in a rapidly changing economy. Indian arts and science undergraduate colleges, which educate a significant proportion of undergraduate students, traditionally had a kind of liberal arts curriculum, with students exposed to various disciplines. However, the specific curriculum has been criticized as outdated and unimaginative. Further, an increasing proportion of Indian undergraduates and especially the most able students choose specialized fields such as management, medicine, or engineering. There has been modest interest in China in the idea of liberal education in a few of the top Chinese universities - mainly motivated by a desire to instill critical thinking and to prepare students for a more complex economy. However, these initiatives have been limited to a small number of universities. Overall, students in both countries experience a rather traditional specialized undergraduate education. Educators and others worry about an outdated curriculum, but little has been done to reform it systematically.

Finally, "Peril and Promise" discussed at some length the importance of high standards of ethics in all aspects of higher education. Meritocratic decisions concerning the appointment and promotion of academic staff, the integrity of research methods, an absence of plagiarism, and others are central to maintaining high levels of probity throughout higher education. Both India and China have experienced persistent lapses in academic ethics over time-and examples of plagiarism, favoritism in appointments, and other problems continue. "Peril and Promise" argued that academic excellence requires high ethical standards-and both countries still require significant attention to these issues.

In our view, much in "Peril and Promise" is highly relevant to both of these academic giants. But, as is clear from this brief discussion, neither country has moved comprehensively to implement 
the report's specific reforms and perspectives. We will proceed to discuss contemporary realities in China and India. Without question, these two countries are centrally important to global higher education, so considering their development is useful for a broader understanding of key trends in higher education.

\section{China vs. India}

According to a report by the British Council, "the OECD predicts that in 2020, 200 million of the world's 25-34 year olds will be university graduates and 40 percent of these will be from China and India" (2014). By 2030, the two countries together are expected to supply more than 60 percent of workers in fields related to science, technology, engineering, and mathematics for G20 countries (OECD 2015). Given this context, examining forces that led to massive expansions of the Chinese and Indian higher education systems in recent years and assessing the quality of instruction offered at these institutions are matters of international concern.

In recent years, China and India recognized the increasingly important role higher education will play in their rapidly modernizing societies. In 1999, China launched a new initiative called the $21^{\text {st }}$ Century Education Revitalization Plan with the intent to drastically expand its higher education system over the next decade. This policy resulted in an annual increase rate of 2 percent for higher education enrollment, doubling enrollments in Chinese universities between 1999 and 2001 alone (British Council 2013). Between 1999 and 2004, the country's ranks of new undergraduate and graduate students increased by 26.1 percent and 28.6 percent, respectively (British Council 2013). Over the past decade and a half, total enrollment figures have continued to rise dramatically in China and India. China now has more students enrolled in tertiary education programs than any country in the world (Altbach 2016). According to figures compiled by UNESCO, China's tertiary enrollment reached 34 million students by 2013 (see Table 1) and 42 million in 2014. That number was up from roughly 7 million in 2000, representing an increase of 363 percent (see Table 2; UNESCO 2015). In terms of tertiary enrollment figures, China is followed by India (28 million in 2013) and the US (20 million in 2013).

As of 2013, China had also quadrupled its output of college graduates over the previous decade, producing approximately 8 million graduates per year from colleges and universities. This puts it ahead of the United States in terms of absolute number of graduates, but not in terms of percentage of the population (Bradsher 2013).

India's enrollment figures have also grown tremendously over the past decade and a half. According to UNESCO, between 2000 and 2013, India's number of tertiary students grew from roughly 9.4 million to a little more than 28 million, representing an increase of nearly 200 percent. Its gross enrollment ratio (GER) rose from roughly 9.5 percent in 2000 to nearly 24 percent in 2013 (UNESCO 2015). In 2015, more than 30 million students attended more than 700 universities and 35,000 colleges (Roberts 2014).

While India's enrollment numbers have increased sharply, it still lags behind much of the world in terms of enrollment ratios (see Figure 2). In 2010, India's GER for tertiary education was 18 percent, while China's was 26 percent. India aims to raise its GER to 30 percent by 2020, which will represent an increase of 14 million students from the total enrollment in 2014 (British Council 2014). According to one estimate offered in 2012, India would need to open one new college per working day to achieve its short-term goals for college enrollment (Lakshmi 2012).

India also lags behind China in terms of producing doctoral graduates. In 2011, India produced approximately 700 engineering PhDs, while China produced roughly 6,000 (Singh 2012). 


\section{Additional Drivers of Growth}

In addition to governmental efforts in expanding higher education, several other forces have helped to drive growth. Demographic changes, economic growth, and increased secondary school graduation rates have factored into the swelling numbers of young people seeking college and university degrees.

\section{Demographic changes}

In 2000, China was home to roughly 97 million people between the ages of 20 and 24. By 2010, that number had reached a high of nearly 130 million before falling back down to 106 million by 2015.

Although India's population of 20- to 24-year-olds has not reached the same heights as China's, it has grown steadily for the past decade and a half. In 2000, the country had roughly 96 million people in that age range. In 2015, the number had grown to 118 million. In no year between 2000 and 2015 did India's population of 20- to 24-year-olds decline (UN Population Division 2015).

Furthermore, the growth in India's youth population is not expected to end for at least another decade (UN Population Division 2015). India is currently home to more than 600 million people under the age of 25, representing more than half of the country's total population (British Council 2014). One-third of the population was under the age of 14 as of 2012. Each year, more than 5 million people enter the 15- to 24-year-old demographic (Garland 2012). By 2020, India will surpass China in having the largest tertiary school-age population in the world (British Council 2014).

\section{Economic growth}

China's workforce has been extremely imbalanced with respect to the distribution of education. A small, highly educated group of managers directs a large, less educated workforce. China's 1999 decision to focus on expanding its higher education system largely stemmed from a desire to achieve greater balance in terms of human capital (Bradsher 2013) and to expand its economy (Yongqiang 2013). In particular, China seeks to compete with Japan, South Korea, and Western countries in the international automobile market. This requires many more educated workers, including specialists in fields such as marketing, engineering, and management (Bradsher 2013).

India will be the world's third largest economy by 2020. Economic development has spurred growth of the country's middle class, which is expected to expand from 50 million people in 2014 to roughly 500 million people by 2025. By the same year, 25 million households will have income equivalent to US\$15,000, which is enough to pay fees for higher education. In total, 15 million more households will be able to afford higher education than could in 2014 (British Council 2014).

\section{Increased secondary school graduation rates}

The increasing numbers of students graduating from high school in China have also contributed to the expansion of higher education. In 1996, only one out of every six 17-year-olds graduated from high school. By 2013, the fraction had grown to three out of five (Bradsher 2013).

India has also made great gains in its primary and secondary education systems, achieving universal primary school education and reducing the number of out-of-school children by more than 90 percent between 2000 and 2015 (Lakshmi 2015). The share of graduates going to higher education grew from 11 percent in 2004 to 23 percent in 2011 (Roberts 2014). 


\section{Focus on science and technology}

The Chinese and Indian education systems have gained attention for the emphasis they place on the STEM fields, i.e., science, technology, engineering, and mathematics. Over the past two decades, China has made a concerted effort to invest in science and engineering, resulting in a greater emphasis on these fields within the realm of higher education. Since the mid-1990s, China has nearly tripled its science and engineering researchers and workers. Between 2000 and 2011, its share of global research and development spending increased from 2.2 percent to 14.5 percent (Neuhauser 2014). Likely due to this increase in available research jobs, many undergraduate students in China choose to study the sciences. In 2008, 31 percent of China's bachelor's degrees were awarded in engineering (compared with 4 percent in the United States), and 51 percent were in the sciences and engineering combined (NMSI 2016).

While India has also pushed to close the gap with the West in terms of science and technology investment, it still lags behind China, the United States, and South Korea when it comes to spending on research and development. In 2011-2012, India invested US\$36.2 billion in research and development, falling short of the US\$205.4 billion, US\$429.1 billion, and US\$58.4 billion investments made by China, the United States, and South Korea, respectively (numbers given in terms of purchasing power parity; Vardhan 2014).

India also falls short of the United States and China when it comes to awarding doctoral degrees. As of 2014, India awarded roughly 4,500 PhDs annually in science and engineering, a total far below the 30,000 awarded in China and 25,000 awarded in the United States. Some signs of change are on the horizon, however. One of the key proposals in India's $12^{\text {th }}$ Five Year Plan called for “establishing 20 'innovation and research universities' and 50 centres of excellence, training and research in science, technology, social sciences and humanities” (British Council 2014).

\section{Challenges Facing Higher Education}

Although China and India's ongoing education booms are cause to celebrate, both countries face significant challenges. India's growth has failed to keep up with the demand its expanding middle class imposes, and both China and India struggle to ensure the quality of their higher education.

India outgrows its supply of schools

While India's enrollment has rapidly increased in response to various forces, the Indian government only recently matched China's $21^{\text {st }}$ Century Education Revitalization Plan with its own centralized effort to expand the higher education system. In 2012, the government released its 12th Five Year Plan, which calls for India to achieve a postsecondary gross enrollment ratio (GER) of 30 percent by 2020 (British Council 2014), up from 24 percent in 2013 (UNESCO 2015). It also calls for a focused effort on improving academic quality, allowing more autonomous governance within the higher education system and bolstering financing for research and infrastructure (Shah 2013).

To achieve its enrollment goals, India must add 14 million university spaces by 2020 according to the British Council (2014). In 2014, Indian President Narendra Modi promised to open 60 new universities, including medical and engineering colleges, mostly in the private sector (Roberts 2014). However, one estimate suggests that the country would need to construct tens of thousands of new colleges and universities over the next few years to keep up with its desired enrollment gains (British Council 2014). Regardless of whether India is able to hit its mark, the government clearly recognizes the necessity of expanding higher education to stay economically competitive in the global market. 


\section{Large disparities in quality}

The rapid expansion of higher education in China and India significantly strained the quality of education for most students. As student-to-faculty ratios have swelled and funds have been diverted to building infrastructure, the level of instruction has suffered in many places. Vast discrepancies exist between the quality of top universities and the quality of average or lower-end universities in both countries.

The general consensus among experts is that the push for quantity has trumped quality when it comes to higher education in China. Demand for faculty has outstripped the supply of qualified candidates. Until 1999, China produced fewer than 10,000 doctoral degrees a year. This means that there are now roughly 3,000 undergraduates for every person who received a doctorate in the 1990s. Many tertiary students end up receiving instruction from professors who either recently graduated, and are therefore inexperienced teachers, or have come out of retirement and rely on outdated knowledge (Bradsher 2013).

Despite the high demand for qualified instructors, many Chinese professors are insufficiently compensated. For some universities, rapid expansion has translated to lower spending on actual education, as a greater proportion of funds has been diverted to construction projects and institutional development (Matthews 2015). In an effort to earn extra pay, some professors maintain multiple ongoing research projects or start side companies, which distracts them from their teaching (Bradsher 2013).

In addition to focusing on growth, China also strongly emphasized elevating a handful of its best universities into the ranks of the international elite. As a result, research funding distribution among the nation's colleges and universities is greatly imbalanced. China's C9 universities (the country's equivalent of the Ivy League) are estimated to have received about 10 percent of the country's research and development spending, while employing only 3 percent of the staff in that field (Matthews 2015).

The substandard quality of instruction many Chinese tertiary students receive may translate into poor employment prospects following graduation. Data from the Chinese Household Finance Survey in 2011 revealed that 16.4 percent of recent graduates were unemployed, and the situation has most likely worsened since then (Matthews 2015). In 2013, only 35 percent of the 7 million undergraduate students about to graduate had found jobs by the end of April, and only 26 percent of postgraduate students had secured employment (Yongqiang 2013).

As with China, many find fault with the quality of India's ever-expanding higher education system, citing low standards for both teaching and research. According to a report by the British Council, "the system is beset by issues of quality in many of its institutions: a chronic shortage of faculty, poor quality teaching, outdated and rigid curricula and pedagogy, lack of accountability and quality assurance and separation of research and teaching" (2014). Because of the country's massive number of tertiary students, student-to-faculty ratios tend to be high in comparison with top international universities (Shah 2013). Research quality also suffers because the high demand for education tends to shift the focus to acquiring new students. No serious funding is available for research as a result (Roberts 2014).

While teaching receives more attention than research, poor pay for professors holds quality of instruction back. Academic pay scales at public universities are sometimes tied to civil service rates, and $\mathrm{PhDs}$ who go into teaching can expect relatively low pay compared with what they would receive in the private sector (Shah 2013). A 2011 government report found that 40 percent of existing faculty positions remained vacant (Singh 2012). 
Unlike China, India has had little success in achieving international recognition for the upper echelon of its research universities. As recently as 2013, no Indian schools were included in the top 200 universities of the Times Higher Education, QS, or Academic Rankings of World Universities (Shanghai) international rankings. Some experts have called for a greater push to develop a strong core of elite institutions (Shah 2013). While the Indian Institute of Science and the Indian Institute of Technology Delhi have managed to climb into the top 200 of the QS rankings (numbers 147 and 179, respectively) over the past few years, Indian schools remain shut out of top spots in the Times Higher Education World University Rankings and Shanghai Academic Ranking of World Universities (see Table 3; QS 2015; Times Higher Education 2015; Shanghai Ranking Consultancy 2015).

Most of India's best universities are public. Some of the most highly regarded universities are the Indian Institutes of Technology and the Indian Institutes of Management. In fact, only public universities have appeared anywhere on the major rankings for international universities in recent years. Despite the supremacy of public schools, more than half of India's tertiary students attend private colleges and universities (in 2013, 58.9 percent attended private institutions; Shah 2013).

\section{The diminished place of liberal education}

China's educational methodology has been criticized as overly “authoritarian” (Matthews 2015). Professors tend toward outmoded means of instruction, relying heavily on lectures rather than workshops or discussions (Bradsher 2013). This is partly due to the limited number of instructors who must teach large numbers of students, but cultural expectations of professors constantly "instructing” students also contribute to the problem. In one survey of 2,500 students from 15 different universities, students said that their learning suffered from an inadequate emphasis on fostering their independence (Matthews 2015).

In addition, students in China are required to specialize at a young age. Most choose their major before reaching college, and once at a university, the typical student only takes a handful of electives (Bradsher 2013). This can make thinking creatively and taking interdisciplinary approaches to solving problems difficult for students.

Up to now, India has also largely overlooked the value of liberal education. In a report from 2014, the British Council wrote that "international collaboration in the arts, humanities and social sciences is generally lacking and there is an anxiety about the recent neglect of these disciplines in India.” However, a small push to create new opportunities in India for students to pursue liberal education recently occurred. For example, several professionals and entrepreneurs came together to found Ashoka University in 2014, with the goal of transforming the school into "the first Ivy League-caliber liberal arts institution in India” (Bearak 2013).

\section{Emphasis on entrance exams}

Some experts see a significant drop-off in Chinese students' work ethic following graduation from high school and entrance into the university system. One potential explanation lies in the extreme significance placed on passing the Gaokao, China's National Higher Education Entrance Examination for secondary school students. With so much riding on one exam, students are left with little internal motivation once they have completed the test and the external motivator has been removed. Essentially, students work extremely hard to pass the Gaokao and tend to burn out by the time they reach college (Matthews 2015).

As in China, massive emphasis is placed on entrance exams for college admissions in India. Final high school examinations are the only criteria for admission to most colleges. Furthermore, the scarcity of quality institutions has led to a situation in which incredibly qualified applicants often 
fail to gain admission to top schools. In some cases, schools require scores higher than 99 percent for admission (Shah 2013). In 2011, the well regarded India Institutes of Technology had an acceptance rate of less than 2 percent out of an applicant pool of roughly 500,000 who qualified for the entrance exam (Najar 2011). Pressure to succeed in the admissions process has in some cases been linked to increased rates of suicide among students (Lakshmi 2016).

\section{Higher education systems and governance}

In 2009, Philip Altbach characterized China and India as having "academic governance arrangements that [were] in some ways dysfunctional." Neither country permits individual universities much self-governance or autonomy. Professors, in particular, have relatively low influence within the higher education systems (Altbach 2009; Altbach 2014).

In China, universities tend to be run by an academically selected president and an executive vice president who is selected by the Communist Party. This administrative setup can produce tension and limits the degree of self-governance possible. Some universities, however, are considering moving toward a more American style of academic leadership, in which more authority is granted to university presidents and department chairs (Altbach 2009).

In India, the government tightly controls most state-run universities, frequently leading to political interference with academic processes, including hiring decisions and implementation of new academic programs. However, private universities, which constitute most schools in India, face far less oversight (Altbach 2009). In fact, private institutions face so little accountability that students occasionally "graduate" from college only to discover that their school was unaccredited and that their degree is worthless. According to one New York Times article, of the more than 31,000 universities and colleges in operation in 2012, only 4,532 were accredited. The same article referred to a report by India's University Grants Commission that listed 21 "fake universities," which were not permitted to confer degrees (Lakshmi 2012).

\section{Outlook for the Future}

China recently shifted focus from growing the quantity of higher education institutions to increasing their quality. In 2010, the country introduced its National Outline for Medium- and Long-Term Educational Reform and Development, laying out China's education plans for the next decade (i.e., through 2020). The plan's focuses for higher education include "increasing the quality of talents and professionals, elevating research capacity, better serving the society, and optimizing the overall higher education structure and developing institutional uniqueness" (British Council 2013).

In its $12^{\text {th }}$ Five Year Plan, India's government declared its intention to improve academic quality, allow more autonomous governance of the university system, and offer better financing for research and infrastructure. At the same time, significant skepticism exists that the country will be able to reach its current goals for gross enrollment (Singh 2012). Some are hopeful that competition to attract students will drive up standards of teaching and research (Roberts 2014).

\section{Conclusion}

Coming at a time of decreasing investment in tertiary education and increasing demand for postsecondary education, "Peril and Promise" argued convincingly for investment in postsecondary education as a means to further economic development. The report also provided some key practical guidance, including recommendations about the importance of the public 
interest in shaping higher education policy, approaches to access of increasingly diverse segments of the population, the role of higher education in instilling democratic values, and others.

Because of the staggeringly rapid growth in China's and India's higher education systems, this article considers the main messages of "Peril and Promise" in the context of these countries' experiences, finding that neither country made much use of the report's recommendations. Both countries could benefit from more systematic thinking about their education systems. Although China has had great success with its upper-tier universities, especially in the areas of science and technology, the lower levels lag in quality, and neither country has emphasized liberal education. In both China and India, the focus on rapid growth has come at the cost of quality. Outmoded and bureaucratic systems of governance and ethical lapses also continue to drag on these countries' postsecondary education. Additional problems are India's inability to keep up with postsecondary education demand and the heavy emphasis on entrance exams in both countries.

However, both countries appear to recognize many of the problems related to their higher education systems, issuing plans to address problems of disparities in quality, governance, access, and more. Attention to creating a comprehensive education system, updating outmoded forms of governance, and emphasizing ethics and liberal education could go a long way toward alleviating many problems these countries face. 


\section{Sidebar 1}

\section{Tsinghua University and the Indian Institute of Science: Comparing Two Top Universities}

Tsinghua University and the Indian Institute of Science consistently rank among the top universities in China and India, respectively. Briefly examining the commonalities and differences between these institutions provides some insight into the different states of elite research universities in these countries.

Tsinghua University ranks $47^{\text {th }}$ on the Times Higher Education World University Rankings for 2015-2016. The only school from mainland China to rank ahead of Tsinghua was Peking University, which came in at number 41 (World University Rankings 2016). According to 2014 statistics published on Tsinghua's English language website, the school had 45,237 registered students. Postgraduates constitute most of the student body, with doctoral students making up a significant plurality; there were 18,296 postgraduate students (other than doctoral candidates) and 11,249 doctoral candidates in 2014. The university consisted of 19 schools and 55 departments at the time (Tsinghua University 2016c).

Tsinghua's academic year is divided into three sessions: autumn, spring, and summer. Undergraduate students complete coursework over the span of two 18-week-long semesters in the fall and spring. In the summer, they are required to pursue practical training or an internship abroad. According to Tsinghua's website, the undergraduate curriculum offers students a "liberal breadth of education." Of the 170 total credits required for graduation, students must earn 35 from the humanities and social sciences, 35 from the natural sciences, 70 from basic and major-related courses, and 30 from practical training. For the first two years, students are encouraged to take a broad selection of classes before selecting their major for the final two years (Tsinghua University 2016a). In total, 74 different undergraduate degree programs are offered (Tsinghua University 2016b).

The Indian Institute of Science (IISc) is the highest ranked Indian university in the Times Higher Education rankings, falling in the range of 251-300 (individual rankings are not given beyond the top 200; World University Rankings 2016). IISc is much smaller than Tsinghua University, with a student body of roughly 3,500, according to the school website. Despite its small size, IISc also emphasizes training doctoral students. The school has roughly 2,200 doctoral students in total, representing more than half of the student body. The school has 39 departments, units, and centers, supported by approximately 500 academic and scientific staff (IISc 2016a).

IISc offers four-year Bachelor of Science programs in six major disciplines: biology, chemistry, earth and environmental science, materials, mathematics, and physics. To round out their education, students must also complete coursework in the humanities and in engineering. For the first three semesters, students take one course each in physics, chemistry, mathematics, biology, engineering, and humanities. By the fourth semester, students must select their major and have the option to pursue a minor. Over the next three semesters, they complete four courses in their major and minor each term, an elective in engineering, and a seminar in the humanities. For the final two semesters, students complete a research project. The university emphasizes interdisciplinary connections among its various fields of undergraduate study (IISc 2016b).

A few commonalities and differences stand out when examining the makeup of the student bodies and the structure of the curricula at these two distinguished schools. Because IISc is a much smaller institution than Tsinghua University, an observer familiar with Western systems of higher education might expect IISc more closely to resemble the liberal arts colleges found in the United States. However, Tsinghua appears to parallel this model more heavily. While IISc only offers undergraduate majors in the sciences, Tsinghua students can choose from a broad array of 
disciplines. Although Tsinghua hosts many more doctoral students, $\mathrm{PhD}$ candidates actually make up a greater percentage of IISc's student body.

Both schools emphasize the importance of immersive education. Tsinghua does this by requiring students to pursue practical training or internships during the summer, while IISc ensures that its students get practical experience by requiring them to complete yearlong research projects. Finally, although IISc is obviously invested in the sciences, both universities seek to offer their students relatively well-rounded educations by requiring them to take at least some coursework in the humanities and social sciences.

\section{Sidebar 2}

\section{Students Turn Abroad}

The difficulty of attaining a spot at top Indian universities has led many of the country's best students to seek education abroad. In fact, American universities have become de facto "safety schools" for strong students who do not achieve top scores on the entrance exam. As of 2011, Indians formed the second largest foreign student group in the United States, after Chinese students. In total, almost 105,000 Indian students attended American schools in 2009-2010 (Najar 2011).

Many Indian families, however, face considerable financial strain if they decide to send their children abroad. The price of high quality education in the United States tends to be much higher than in India. For example, in 2011, annual tuition costs at Dartmouth came to US\$41,736, while tuition at Delhi University ranged from US\$150 to US\$500 per year. At the same time, the incomes of some middle-class Indian families are much lower than those of their Western counterparts. According to one New York Times article, "some middle-class salaries in India are below the poverty line in the West," making it very difficult to afford a university education at an American institution (Najar 2011). 
Tables and Figures

Table 1. Selected enrollment data, 2000-2013

\begin{tabular}{|c|c|c|c|c|c|c|}
\hline & China & & & India & & \\
\hline Indicator & 2000 & 2003 & 2013 & 2000 & 2003 & 2013 \\
\hline $\begin{array}{l}\text { Enrollment in tertiary education, all } \\
\text { programs, both sexes (number) }\end{array}$ & $7,364,111$ & $15,186,217$ & $\begin{array}{l}34,091,29 \\
0\end{array}$ & $9,404,460$ & $11,295,041$ & $28,175,135$ \\
\hline $\begin{array}{l}\text { Enrollment in tertiary education, all } \\
\text { programs, female (number) }\end{array}$ & NA & $6,657,178$ & $\begin{array}{l}17,290,09 \\
1\end{array}$ & $3,552,026$ & $4,342,409$ & $12,942,452$ \\
\hline $\begin{array}{l}\text { Enrollment in tertiary education, all } \\
\text { programs, male (number), calculated }\end{array}$ & NA & $8,529,039$ & $\begin{array}{l}16,801,19 \\
9\end{array}$ & $5,852,434$ & $6,952,632$ & $15,232,683$ \\
\hline $\begin{array}{l}\text { Enrollment in tertiary education per 100,000 } \\
\text { inhabitants, both sexes }\end{array}$ & 580 & 1,176 & 2,502 & 893 & 1,019 & 2,202 \\
\hline $\begin{array}{l}\text { Enrollment in tertiary education per } 100,000 \\
\text { inhabitants, female }\end{array}$ & NA & 1,061 & 2,617 & 700 & 813 & 2,101 \\
\hline $\begin{array}{l}\text { Enrollment in tertiary education per } 100,000 \\
\text { inhabitants, male }\end{array}$ & NA & 1,285 & 2,394 & 1,072 & 1,211 & 2,296 \\
\hline $\begin{array}{l}\text { Gross enrollment ratio, tertiary, both sexes } \\
\text { (\%) }\end{array}$ & 7.72 & 15.64 & 30.16 & 9.55 & 10.67 & 23.89 \\
\hline Gross enrollment ratio, tertiary, female (\%) & NA & 14.11 & 32.22 & 7.50 & 8.54 & 23.06 \\
\hline Gross enrollment ratio, tertiary, male (\%) & NA & 17.08 & 28.30 & 11.44 & 12.65 & 24.64 \\
\hline $\begin{array}{l}\text { Percentage of graduates from tertiary ISCED } \\
6^{*} \text { programs who are female }(\%)\end{array}$ & NA & NA & 50.13 & NA & NA & 49.23 \\
\hline
\end{tabular}

Source: UNESCO (2015).

* ISCED (International Standard Classification of Education) 6 programs include bachelor's and other equivalent tertiary programs. 
Table 2. Percent change between 2000 and 2013

\begin{tabular}{|l|l|l|}
\hline \hline Indicator & China & India \\
\hline Enrollment in tertiary education, all programs, both sexes (number) & $362.94 \%$ & $199.59 \%$ \\
\hline Enrollment in tertiary education per 100,000 inhabitants, both sexes & $331.50 \%$ & $146.67 \%$ \\
\hline Gross enrollment ratio, tertiary, both sexes (\%) & $290.68 \%$ & $150.23 \%$ \\
\hline
\end{tabular}

Source: UNESCO (2015).

Table 3. Times Higher Education World University Rankings, 2015-2016

\begin{tabular}{|l|l|l|l|}
\hline \hline Ranking & Number from China & Number from India & Total \\
\hline Top 50 & 2 & 0 & 2 \\
\hline Top 100 & 2 & 0 & 2 \\
\hline Top 250 & 4 & 0 & 4 \\
\hline Top 500 & 11 & 5 & 16 \\
\hline Top 800 & 36 & 17 & 53 \\
\hline
\end{tabular}

Source: Times Higher Education (2015). 
Figure 1. Total tertiary enrollment (in millions), 2000-2013

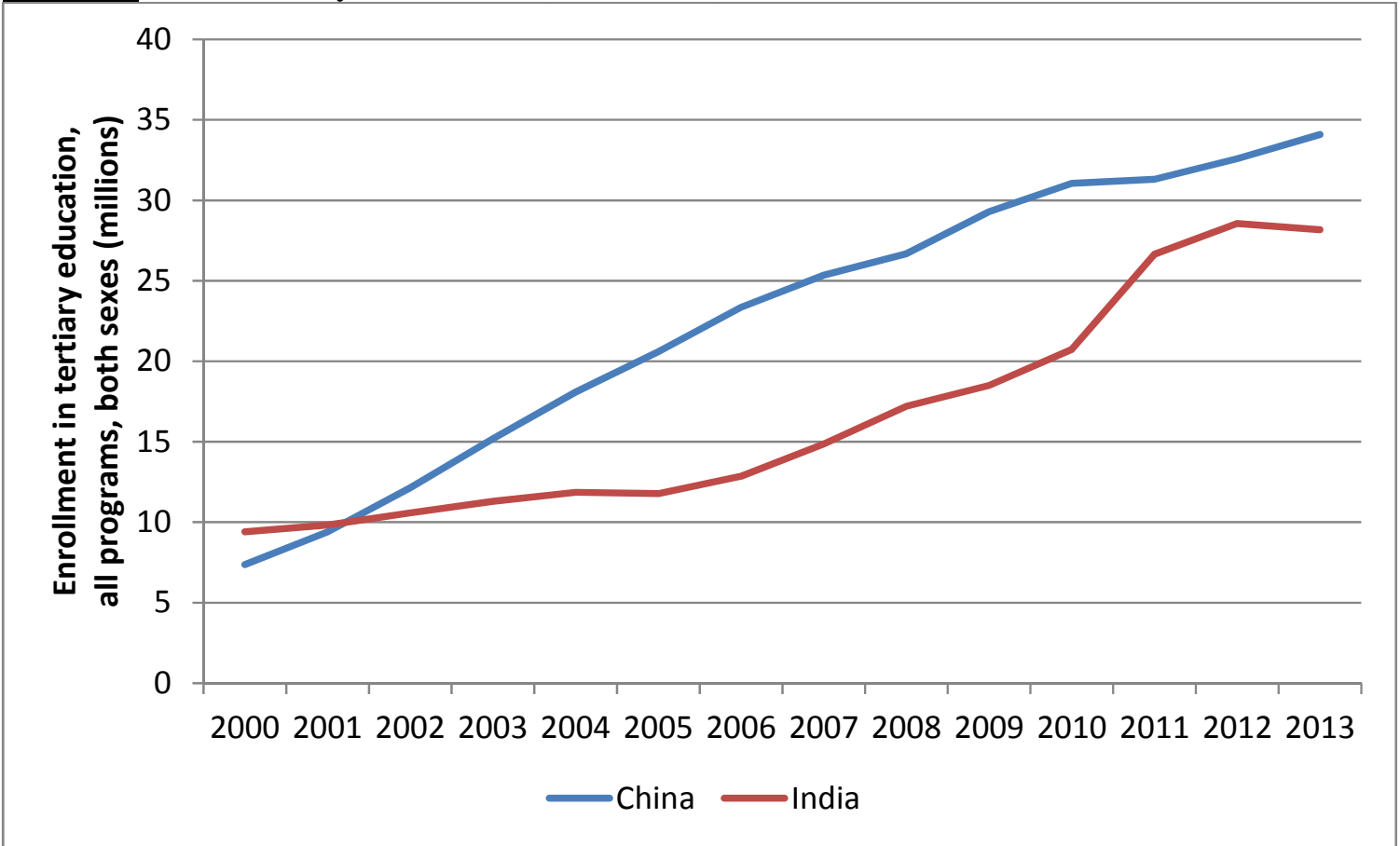

Source: UNESCO (2015).

(Note to Figure 1: Tertiary enrollment in China rose sharply from 34 million in 2013 to 42 million in 2014. Further research into the nature of this sharp jump is warranted. For India, 2014 data are not yet available.) 
Figure 2. Tertiary gross enrollment ratio, 2000-2013

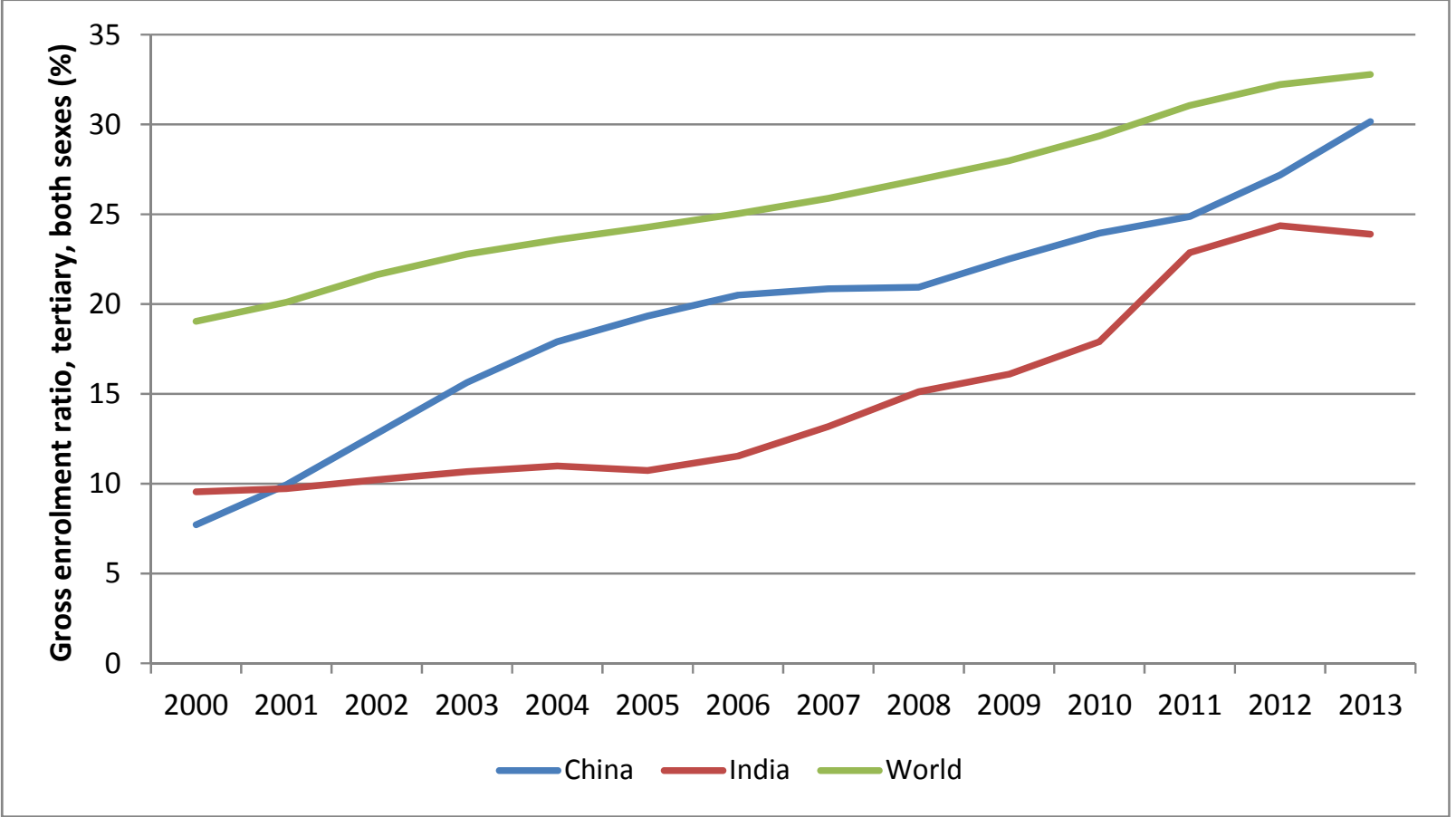

Source: UNESCO (2015).

(Note to Figure 2: In 2014, gross enrollment in tertiary education rose from 30 percent to 39 percent. Further research is needed to understand the nature of this jump. For India, 2014 data are not yet available.) 


\section{References}

Altbach, P. G. (2009). "The giants awake: Higher education systems in China and India." Economic and Political Weekly, 44(23), 39-51.

Altbach, P. G. (2014). “India’s higher education challenges.” Asia Pacific Education Review 15(4), 503-510.

Altbach, P. G. (2016). “China's glass ceiling and feet of clay.” University World News, February 19. http://www.universityworldnews.com/article.php?story=20160217143711361.

Altbach, P. G., Reisberg, L., and Rumbley, L. (2010). Trends in global higher education: Tracking an academic revolution. Rotterdam, Netherlands: Sense Publishers.

Bearak, M. (2013). “A new university offers liberal arts as higher education alternative.” The New York Times, November 26. http://india.blogs.nytimes.com/2013/11/26/a-new-universityoffers-liberal-arts-as-higher-education-alternative/.

Bradsher, K. (2013). "Next made-in-China boom: College graduates.” The New York Times, January 16. http://www.nytimes.com/2013/01/17/business/chinas-ambitious-goal-for-boomin-college-graduates.html?_r=0.

British Council. (2013). "A brief overview of Chinese higher education system." https://www.britishcouncil.in/sites/default/files/higher_education_system_of_china.pdf.

British Council. (2014). "Understanding India: The future of higher education and opportunities for international cooperation.” https:/www.britishcouncil.org/sites/default/files/ understanding_india_report.pdf.

Garland, S. (2012). "In India, a college building boom.” The Washington Post, January 1. https://www.washingtonpost.com/local/education/in-india-a-college-buildingboom/2011/12/21/gIQAxl0oUP_story.html

Indian Institute of Science (IISc). (2016a). “About us.” http://www.iisc.ernet.in/aboutiisc/generalinformation.php.

Indian Institute of Science (IISc). (2016b). “Academic details of the programme.” http://www.iisc.ernet.in/ug/academic_details.html.

Lakshmi, R. (2012). "India's university system is in 'deep crisis.”' The Washington Post, March 27. https://www.washingtonpost.com/world/asia_pacific/indias-university-system-in-deepcrisis/2012/03/20/gIQAzUOgdS_story.html.

Lakshmi, R. (2015). "India's schools now have an equal ratio of girls and boys, and that's a big deal.” The Washington Post, April 9. https://www.washingtonpost.com/news/worldviews/ wp/2015/04/09/indias-schools-now-have-an-equal-ratio-of-girls-and-boys/.

Lakshmi, R. (2016). “A spate of suicides highlight the pressures on students in India.” The Washington Post, January 24. https://www.washingtonpost.com/world/asia_pacific/a-spateof-suicides-highlights-the-pressures-on-students-in-india/2016/01/23/8ca5d7de-acbf-11e5b281-43c0b56f61fa_story.html.

Matthews, D. (2015). “Assessing China’s academic orbit.” Times Higher Education, March 5. https://www.timeshighereducation.com/features/assessing-chinas-academicorbit/2018805.article.

Najar, N. (2011). “Squeezed out in India, students turn to U.S.” The New York Times, October 13. http://www.nytimes.com/2011/10/14/world/asia/squeezed-out-in-india-students-turn-tounited-states.html.

National Math and Science Initiative (NMSI). (2016). "STEM education statistics." https://www.nms.org/AboutNMSI/TheSTEMCrisis/STEMEducationStatistics.aspx. 
Neuhauser, A. (2014). "STEM study: China, Asia 'catching up' to 'less dominant' U.S.” U.S. News, February 6. http://www.usnews.com/news/stem-solutions/articles/2014/02/06/stemstudy-china-asia-catching-up-to-less-dominant-us.

Organisation for Economic Co-operation and Development (OECD). (2015). "Educators' indicators in focus.” http://www.oecd.org/education/EDIF\%2031\%20(2015)--ENG--Final.pdf.

Psacharopoulos, G. (1994). "Returns to investment in education: A global update." World Development 22(ISS?), 1325-43.

QS. (2015). “QS World University Rankings 2015/16.” http://www.topuniversities.com/university-rankings/world-university-rankings/2015.

Roberts, A. (2014). "India's university challenge.” The Economist, November 20. http://www.economist.com/news/21631948-big-quantity-short-quality-indias-universitychallenge.

Shah, G. R. (2013). "Indian universities still lag in world rankings." The New York Times, November 24. http://www.nytimes.com/2013/11/25/world/asia/indian-universities-still-lagbehind-in-world-rankings.html.

Shanghai Ranking Consultancy. (2015). “Academic ranking of world universities 2015.” http://www.shanghairanking.com/ARWU2015.html.

Singh, V. (2012). "India's education dream risks remaining just that." The New York Times, January 15. http://www.nytimes.com/2012/01/16/world/asia/16iht-educlede16.html.

Task Force on Higher Education and Society (Task Force). (2000). "Higher education in developing countries: Peril and promise”. Washington, DC: The World Bank.

Times Higher Education. (2015). "World university rankings 2015-2016." https://www.timeshighereducation.com/world-university-rankings/2016/world-ranking.

Tsinghua University. (2016a). “Curriculum.” http://www.tsinghua.edu.cn/publish/newthuen/newthuen_cnt/admissions/admissions-13.html.

Tsinghua University. (2016b). "Degree programs.” http://www.tsinghua.edu.cn/publish/newthuen/newthuen_cnt/admissions/admissions-11.html.

Tsinghua University. (2016c). "Statistics." http://www.tsinghua.edu.cn/publish/newthuen/newthuen_cnt/about-th/about-5.html.

UN Department of Economic and Social Affairs Population Division. (2015). "World population prospects, the 2015 revision." http://esa.un.org/unpd/wpp/.

UNESCO. (2015). “Institute for statistics.” http://data.uis.unesco.org/.

Vardhan, H. (2014). "India lags behind US, China, and Korea in science and technology investment.” The Times of India, November 28. http://timesofindia.indiatimes.com/india/India-lags-behind-US-China-and-Korea-in-scienceand-technology-investment/articleshow/45303411.cms.

World University Rankings. (2016). Times Higher Education. https:/www.timeshighereducation.com/world-university-rankings/2016/worldranking\#!/page/0/length/25.

Yongqiang, G. (2013). “In China, higher education brings few guarantees.” TIME, July 4. http://world.time.com/2013/07/04/in-china-higher-education-brings-few-guarantees/. 